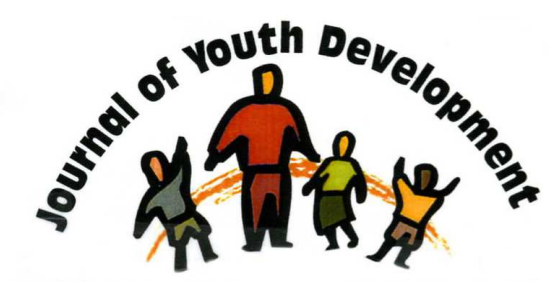

Bridging Research \& Practice

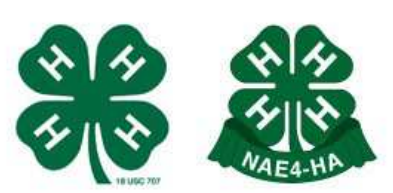

\title{
On a Pathway Towards Thriving: \\ Evaluating the Effectiveness of Tools to Promote Positive Development and Intentional Self Regulation in Youth
}

\author{
Edmond P. Bowers \\ Tufts University \\ Medford, MA \\ Ed.Bowers@tufts.edu \\ Christopher M. Napolitano \\ Tufts University \\ Medford, MA \\ Miriam R. Arbeit \\ Tufts University \\ Medford, MA \\ Paul Chase \\ Tufts University \\ Medford, MA \\ Samantha A. Glickman \\ Tufts University \\ Medford, MA \\ Richard M. Lerner \\ Tufts University \\ Medford, MA \\ Jacqueline V. Lerner \\ Boston College
}

Institute for Applied Research in Youth Development 


\title{
JOURNAL OF YOUTH DEVELOPMENT \\ bridging research and practice

\section{On a Pathway Towards Thriving: \\ Evaluating the Effectiveness of Tools to Promote Positive Development and Intentional Self Regulation in Youth}

\author{
Edmond P. Bowers, Christopher M. Napolitano, Miriam R. Arbeit, Paul Chase, \\ Samantha A. Glickman and Richard M. Lerner \\ Tufts University \\ Jacqueline V. Lerner \\ Boston College
}

\begin{abstract}
This article provides initial data about the reliability and validity of tools aimed at promoting youth intentional self regulation (ISR) within mentoring programs. Based on the translation of the theory-based research about ISR and youth thriving conducted within the 4-H Study of Positive Youth Development (PYD), the GPS to Success tools use the metaphor of a car's GPS navigational system to enhance goal-directed behaviors among youth. The core GPS tools are "growth grids," designed to help mentors appraise ISR skill development and to link these skills to other grids assessing the Five Cs of PYD and Contribution. Data from 152 mentor and youth pairs from 4-H program sites in Oregon and North Carolina indicated that the growth grids were generally reliable. Although validity evidence was mixed, rubrics for " $G$ " and "P" and for a global GPS score were related to a well-validated measure of ISR.
\end{abstract}

\section{Introduction}

Evidence from several fields suggests that intentional self-regulatory, or goal-directed, skills become especially important to healthy development during adolescence (e.g., Cunha, Heckman, \& Schennach, 2010; Geldhof, Little, \& Columbo, 2010; Gestsdóttir, \& Lerner, 2008; Lerner, Lerner, Bowers, Lewin-Bizan, Gestsdottir, \& Urban, 2011). The salience of intentional self-regulation (ISR) during adolescence is grounded in the multifaceted changes that mark the second decade of life, and the need to regulate, or control, adaptively one's behavior in the face 
of changes involving: the brain (Moshman, 2013; Paus, 2009); new motivational states (Freud, 1969; Susman, \& Dorn, 2009); cognitive changes (Kuhn, 2009); and the refinement of longterm planning skills (Brandtstädter, 1989; McClelland, Ponitz, Messersmith, \& Tominey, 2010).

Philosophers, philanthropists, and practitioners share with developmental scientists the belief in the salience of ISR for positive youth development (PYD). For instance, Sir John Templeton (2012) explained that the key to character development is the control of one's mind, noting that "If one rules one's mind, one rules one's world" (2012, p. 3). In turn, practitioners have great interest in integrating ISR skills into youth development programs (e.g., Kurtines, et al., 2008b; J. Lerner, et al., 2012). Indeed, not only are youth development programs key ecological assets in promoting ISR, PYD, and youth Contribution to their communities but, as well, the adults in the lives of youth - and particularly the presence of competent, reliable, and devoted adults are the key features of effective youth development programs (see, for reviews, J. Lerner, et al., 2012; Lerner, 2004; Rhodes, \& Lowe, 2009).

However, there are few evidence-based tools available to help practitioners discuss and build ISR skills with the youth in their care. The purpose of this report is to provide initial data about the use and validity of research-based tools aimed at promoting ISR in the context of mentoring programs. These materials - GPS to Success - are a translation of the theory-predicated research conducted within the 4-H Study of PYD (Lerner, et al., 2005, 2009, 2010, 2011b) about the links between youth ISR and positive development.

\section{Designing the GPS to Success tools}

The core components of the GPS to Success project are based on a translation of theory and research pertinent to the Selection (S), Optimization (O), and Compensation (C; SOC) model of ISR (Baltes, \& Baltes, 1990; Baltes, Lindenberger, \& Staudinger, 2006; Freund, \& Baltes, 2002; Freund, Li, \& Baltes, 1999). The project uses the metaphor of a car's GPS navigation system you "choose your destination" and the GPS (your SOC skills in this case) provides "strategies" to arrive at your destination (in this case, achieving a goal). In Project GPS, "G" stands for "Goal Selection," and reflects Selection skills. "P" stands for "Pursuit of Strategies," and reflects Optimization skills. "S" stands for "Shifting Gears," and reflects Compensation skills. The definitions of these concepts are:

Goal Selection: A young person who has positive purpose is also one who is on a thriving path. Therefore, young people need to understand the importance of selecting positive goals and of having the skills to make good choices;

Pursuit of Strategies: Adolescents need to develop strategies to attain their goals. They need to be able to make goal-specific plans and to develop appropriately the resources - from practicing a skill to recruiting the help of others - to achieve their goals; and

Shifting Gears: Youth must be able to switch to a new strategy when their initial strategy fails to help achieve their goal. In these circumstances, they need to judge when it is reasonable to stay with their original goals and when it is prudent to select a new goal, for instance, when the chance to attain the initial goal is lost.

The core tools for GPS to Success are rubrics or "growth grids." The growth grids provide a standardized way for youth and mentors to discuss GPS skills and the Five Cs of Positive Youth Development (PYD); i.e., Competence, Confidence, Connection, Character, and Caring; (Lerner, et al., 2005, 2009, 2010, 2011b) and the " 6 th $C$ " of youth, Contribution. Growth grids were also designed to give mentors a snapshot on how youth in their programs were doing, and what the goal-management skills of youth look like. The growth grids also helped mentors appraise skill 
development. This tool enables mentors to assess how well youth in a program have benefitted from their involvement with mentors. The growth grids, however, are not just measurement tools. They can also serve as powerful motivators for change in youth (Andrade, 2000; Goodrich,1997; Marzano, \& Haystead, 2008; Moskal, 2003; Popham, 1997). An essential feature of GPS to Success is having both mentor-scored growth grids, in which the mentors assess the youth, as well as youth-scored growth grids, in which the youth do a self-assessment. With the growth grids as a guide, the mentor and youth can compare their assessments of the youth's GPS Skills and PYD - and discuss where they share opinions or where they differ. Youth can see where their greatest strengths lie, and where their biggest challenges exist as they move on a path towards thriving.

In other words, the growth grids were developed for use by both mentors in diverse youth programs and, as well, by the young people they serve. The growth grids were created based upon four design criteria:

1. The use of research evidence for content. Substantive material for the cells of (the vocabulary used in) the growth grids was drawn from findings from the 4-H Study of Positive Youth Development (Lerner, et al., 2005, 2009, 2010, 2011) and the work of Paul Baltes, Alexandra Freund, and their colleagues (e.g., Baltes, 1997; Baltes, \& Baltes, 1990; Baltes, Lindenberger, \& Staudinger, 2006; Freund, \& Baltes, 2002; Freund, Li, \& Baltes, 1999).

2. Aligning terminology with the language of the Thrive Foundation for Youth. When supported by research evidence, variations in terminology were introduced to align wording with the phrasing used by the Thrive Foundation (http://www.thrivefoundation.org/), which drew their content from both the sources noted in Point 1, above, and Point 3, below.

3. The use of cross-validating evidence. The content of the cells of the growth grids were modified to incorporate relevant findings of researchers other than those associated with the 4-H Study or the Baltes, Baltes, and Freund group. Specifically, the work of Peter Benson (2008), William Damon (2008), Carol Dweck (2006), Jacquelynne Eccles (2004), and Reed Larson (2000, 2006) was used.

4. Measurement equivalence across age and phases of program implementation. To reach a large number of diverse youth, the tools that were developed had to be applicable to diverse young people across the adolescent years and, as well, to diverse youth-serving programs at all points in the process of program implementation (from program initiation to termination). Accordingly, we aimed to develop tools that would have validity at any point in time at which they are used (with "time" referring to both age of adolescent and phase of the program he or she is in).

Each growth grid was designed based upon, first, Design Criterion 1 noted above. Accordingly, the language used in the research was transformed into the language within the cells of each rubric. As such, we made changes in this language only if we found through pretesting and research team consensus that Design Criteria 2 or 3 made the tool more useful. Following this procedure helped ensure that we had clearly stated terms for each growth grid.

In regards to pretesting, initial reviews of the tools were conducted with youth-serving professionals and the research team. Youth-serving professionals were asked to evaluate the growth grids in terms of

1. the relevance of the included dimensions to the construct of Goal Selection, Pursuit of Strategies, or Shifting Gears

2. the clarity of the columns of each rubric 
3. the distinction between and logical progression of the performance levels

4. how reliably they can envision each dimension being scored by mentors

5. the usefulness of the rubrics for youth development and in their organizations

6. how to adjust the language of the rubrics to make them more appropriate for adolescents to score themselves.

This series of conversations resulted in a set of growth grids which were then empirically examined with a sample of mentors and youth from 4-H program sites in Oregon and North Carolina. These assessments constituted an initial evaluation of the psychometric usefulness of the GPS to Success tools. That is, this work involved validation procedures that assessed the presence within youth of relations between scores derived from the tools that are pertinent to goal-related behavior and scores derived from the tools pertinent to the Cs. We report here the results of this examination.

\section{Method}

\section{Sample}

There were 152 unique mentor/mentee pairs that participated. Of these participants, 69 of these pairs included youth older than 14 years of age (older adolescents; Mean age $=15.84$, $S D=1.21$ ), and 83 included youth younger than 14 years of age (younger adolescents; Mean $a g e=12.00, S D=1.20$ ). This evaluation was conducted in the fall of 2010 with mentors and mentees at eight 4-H sites in North Carolina and ten 4-H sites in Oregon. Participants from the former state constituted $30.9 \%$ of the sample.

Of the 69 older adolescents who participated in the study, 30.4\% were male, $52.2 \%$ were female, and $17.4 \%$ did not report their gender. Older adolescents' grade in school ranged from "8th Grade" to "12th Grade." Of these 69 participants, 2.9\% of participants were in 8th Grade, $24.6 \%$ of participants were in 9th Grade, $15.9 \%$ of participants were in 10 th Grade, $15.9 \%$ of participants were in 11th Grade, $14.5 \%$ of participants were in 12th Grade, and $26.1 \%$ of participants did not report their grade in school. A large proportion of the older adolescent sample reported being White or Caucasian (72.5\%), whereas $10.1 \%$ reported being AfricanAmerican or Latino/a, and $17.4 \%$ of youth did not report their race or ethnicity.

Of the 83 younger adolescents who participated in the study, 36.1\% were male, $51.8 \%$ were female, and $12.0 \%$ did not report their gender. Younger adolescents' grade in school ranged from "3rd Grade" to "8th Grade." Of these 83 participants, 1.2\% of participants were in 3rd Grade, $3.6 \%$ of participants were in 4th Grade, $20.5 \%$ of participants were in 5th Grade, $24.1 \%$ of participants were in 6 th Grade, $18.1 \%$ of participants were in 7 th Grade, $20.5 \%$ of participants were in $8^{\text {th }}$ Grade, and $12.0 \%$ of participants did not report their grade in school. A large proportion of the younger adolescent sample also reported being White or Caucasian (73.5\%), whereas $8.4 \%$ reported being African-American, $8.4 \%$ reported Other races/ethnicities (Latino/a, Asian American, Native-American), and $12.0 \%$ of youth did not report their race or ethnicity.

In total 45 mentors reported on these 152 youth. Mentors reported on youth indices for a range of one to seven youth (15.5\% reported on one youth, $24.4 \%$ reported on two youth, $13.3 \%$ reported on three youth, $15.5 \%$ reported on four youth, $20.0 \%$ reported on five youth, and $11.1 \%$ reported on 6 or 7 youth). A substantial majority of mentors were female $(80 \%)$ and ranged in age from 25 to $68(M=46.95, S D=9.18)$. A majority of mentors also reported being White or Caucasian $(82.2 \%)$, with $8.9 \%$ reported being, African-American, Latino/a, or Native American, and $8.9 \%$ not reporting their race or ethnicity. 


\section{Rubrics/Growth Grids}

The growth grids involve the different aspects and skills of GPS and PYD to help both youth and their mentors reflect on the youth's strengths and areas for improvement. The grids provide a standard of performance needed to attain a specific score. Each growth grid in the GPS to Success suite has a comparable structure. This structure expedites responding and minimizes scoring error, regardless of the age of the youth or the skill being assessed.

Each of the growth grids shares the same " 1 to 5 " scoring scale. The youth moves up in the scoring scale as they improve along two axes: skill initiative and skill competence. In other words, youth need to have both the initiative to try to use a skill and the competence to implement that skill effectively. For example, a youth at a Level 5 on the rubric is showing consistent initiative to use a particular skill and has mastered the skill. At the opposite end of the spectrum is a youth at Level 1; a youth at Level 1 shows so little initiative or skill, that the youth is disengaged from the process. In between these extremes, a youth at a Level 3 has the initiative to use a particular skill, but needs a lot of help to actually use the skill. At the onset of the GPS to Success project, we expected that we were not likely to find many young people at a Level 5 or a Level 1; however, we expected that many youth would fall between these extremes. Figure 1 presents an example of a Growth Grid.

Assessments of an adolescent's GPS skills and levels of PYD through the growth grids were completed by both youth and mentors. Youth self-assess their abilities, and mentors assess the behavior of youth as well. Having multiple reporters of these intentional self-regulation skills addresses a limitation in the research, in which assessments of an adolescent's SOC were only comprised of self-reported data. The language is different in the mentor versus youthcompleted growth grids to reflect who is scoring them; that is, the youth-completed growth grids are phrased as "I statements" and contain simpler language than the mentor-completed grids. Regardless of these language differences, the content of the rubrics, as well as the overall structure, is shared across the sets of rubrics.

The rubrics also differ by the age of the youth who is the focus of the rubrics. It is important to note that youth ages 10-13 have a single GPS rubric, while youth ages 14-18 have three rubrics assessing $G, P$, and $S$ skills separately. The reason for this difference is based on research which indicated that while it is important for younger adolescents to have goal-directed skills, the $\mathrm{G}, \mathrm{P}$, and $\mathrm{S}$ scores of these adolescents do not differentiate into the tripartite SOC structure identified in older adolescents and adults (Gestsdottir, \& Lerner, 2007). Younger adolescents with high $G$ also have high $P$ and also have high $S$. These younger adolescents also have a difficult time with certain questions on the GPS survey as young people from ages 10-13 often display less-refined and a smaller number of GPS skills. Therefore, the concepts related to those questions were removed, and the single rubric was developed.

Based upon the theoretical and empirical literature and the iterative process with both colleagues at the Thrive Foundation for Youth and youth-serving professionals, we identified 13 skills that were indicative of SOC and related to successful goal attainment. As indicated, we translated these skills into a more practitioner- and youth friendly acronym - GPS - using the metaphor of a car's GPS navigation system:

- The four Goal Selection skills were

○ Choosing your destination,

- Choosing goals that help others,

- Breaking down long-term goals, and

○ Identifying relations among goals. 
- $\quad$ The five Pursuit of Strategies skills were

- Sticking to a plan,

- Seizing the moment,

- Developing strategies,

- Showing persistent effort, and

o Checking your progress.

- The four Shifting Gears skills were

- Substituting strategies,

- Seeking different help,

- Adopting strategies of others, and

$\circ$ Changing goals without feeling bad.

An example of one of the growth grids, indexing an older adolescent's self-assessed "Goal Selection," is presented here, in Figure 1. 


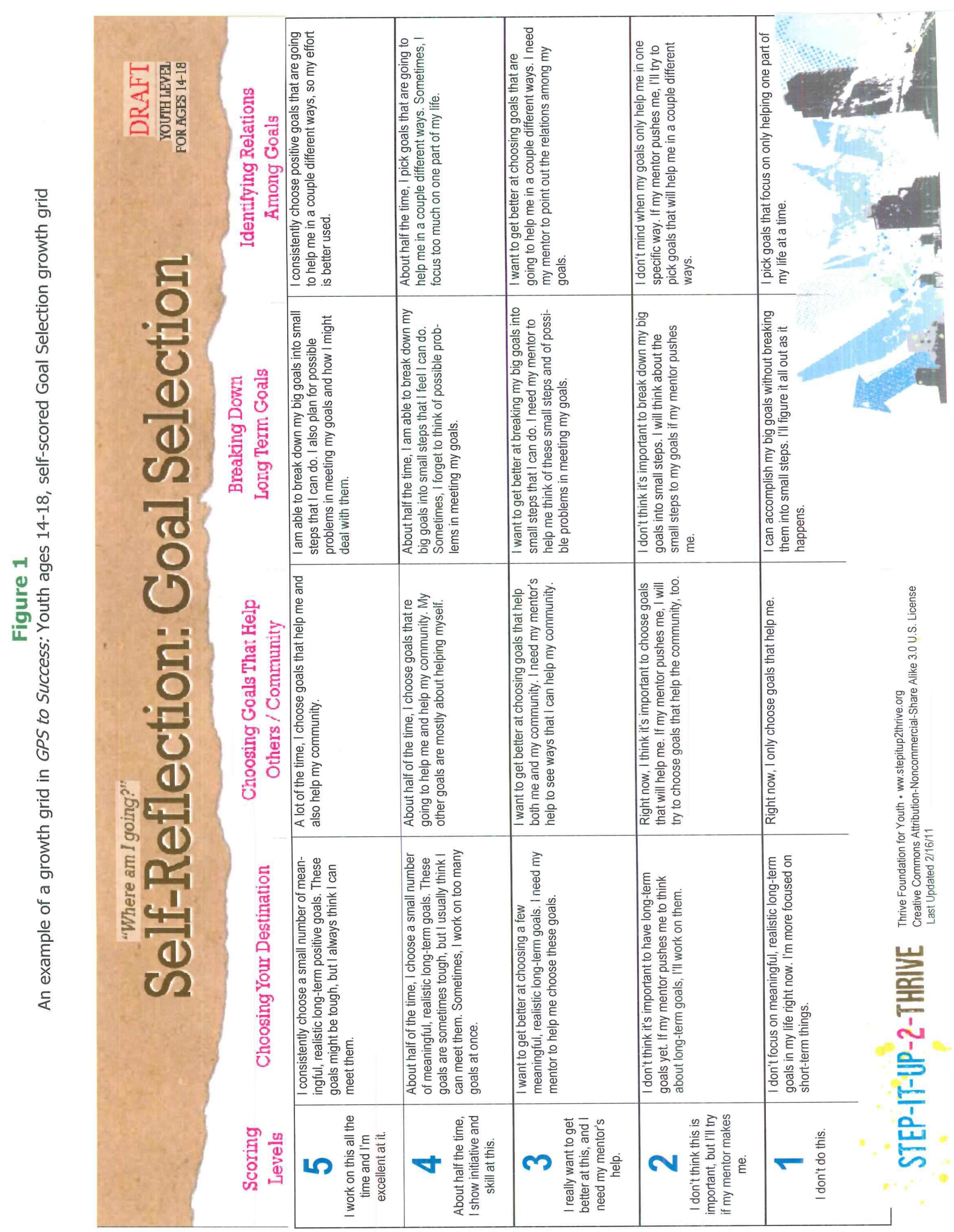

For full set of growth grids, please contact the first author. 
We also identified attributes indicative of each of the Cs of PYD and Contribution (see Appendix 1). The five Competence dimensions were Academic competence, Cognitive competence, Social competence, Emotional competence, and Healthy habits; the five Confidence dimensions were Overall Confidence, Confidence in School, Confidence in Physical Appearance, Confidence in Peer Acceptance, and Confidence in an Area of Interest; the three Connection dimensions were Connection with family, Connection with friends and peer groups, and Connection with community; the three Character dimensions were Moral compass, Integrity; and the four Caring dimensions were Sympathy, Empathy, Caring actions, and Promoting social justice. The four Contribution dimensions were Service to community, Leadership roles, Mentoring peers, and Sense of positive purpose.

Positive Youth Development. Youth also completed measures of PYD. As noted, we utilized the approach to PYD used by Lerner and colleagues (2005) that employs several measures to index PYD, which is operationalized through the assessment of the Five Cs-Competence, Confidence, Character, Connection, and Caring. Each "C" comprises a number of well-validated scales designed to assess the essential elements of the definition of the construct. Detailed information regarding the measurement of each of the Cs is presented below. The Five Cs comprising the PYD construct are operationalized as follows:

Competence is a positive view of one's action in domain-specific areas including the social and academic domains and is indexed by 11 items. Cronbach's alpha for the older adolescents in the present sample was .85. Cronbach's alpha for the younger adolescents in the present sample was .82.

Confidence is an internal sense of overall positive self-worth, identity, and feelings about one's physical appearance and was indexed by 16 items. Cronbach's alpha for the older adolescents in the present sample was .90. Cronbach's alpha for the younger adolescents in the present sample was .80 .

Character involves respect for societal and cultural rules, possession of standards for correct behaviors, a sense of right and wrong, and integrity and was indexed by 20 items. Cronbach's alpha for the older adolescents in the present sample was .87 Cronbach's alpha for the younger adolescents in the present sample was .87.

Connection involves a positive bond with people and institutions that are reflected in healthy, bidirectional exchanges between the individual and peers, family, school, and community in which both parties contribute to the relationship. Connection is indexed by 22 items. Cronbach's alpha for the older adolescents in the present sample was .89. Cronbach's alpha for the younger adolescents in the present sample was .91.

Caring is the degree of sympathy and empathy, that is, the degree to which participants feel sorry for the distress of others and was indexed by 9 items. Cronbach's alpha for the older adolescents in the present sample was .79. Cronbach's alpha for the younger adolescents in the present sample was .63.

Full details about these measures, their construction, and validity and reliability can be found in Lerner and colleagues (2005) and Bowers and colleagues (2010).

Contribution. Participants responded to twelve items which were weighted and summed to create a composite score of contribution. These items were from four subsets: leadership, service, helping, and ideology. Items from the leadership, service, and helping scales measured the frequency of time youth spent helping others (e.g., friends or neighbors), providing service to their communities, and acting in leadership roles; together, the leadership, service, and 
helping subsets comprise an action component of Contribution. The ideology scale measured the extent to which contribution was an important facet of their identities (e.g., "It is important to me to contribute to my community and society"). These items are derived from existing instruments with known psychometric properties and used in large-scales studies of adolescents, that is, the Profiles of Student Life-Attitudes and Behaviors Survey (PSL-AB; Benson, Leffert, Scales, \& Blyth, 1998) and the Teen Assessment Project Survey Question Bank (TAP; Small, \& Rodgers, 1995). The action and ideology components are weighted equally to calculate the Contribution scores. As with the PYD scores, in the present study the Contribution scores range from 0 to 100 . Cronbach's alpha for the older adolescents in the present sample was .75. Cronbach's alpha for the younger adolescents in the present sample was .79.

Intentional self regulation. We used the Selection, Optimization, and Compensation (SOC) questionnaire (Freund, \& Baltes, 2002) to measure self regulation, that is, the individual component of the process of individual-context relations. The original SOC measure, which was created in Germany for use with adult populations, includes 48 items (12 items in each subscale of Elective Selection, Loss-based Selection, Optimization, and Compensation). Freund and Baltes (2002) created a shorter version of this measure, which included six items per scale and had acceptable psychometric characteristics (Freund, \& Baltes, 2002).

Each of the subscales has six items with a forced-choice format. Each item consists of two statements, one describing behavior reflecting Elective Selection, Loss-based Selection, Optimization, or Compensation and the other describing a non-SOC related behavior. An example of an Optimization scale item is: "When I do not succeed right away at what I want to do, I don't try other possibilities for very long OR I keep trying as many different possibilities as are necessary to succeed at my goal." The latter option reflects goal-optimization. Participants are asked to decide which of the statements is more similar to how they would behave. Affirmative responses are summed to provide a score for each individual on each subscale. Higher scores on each subscale indicate higher levels of self-regulatory skills.

Past research using data from the 4-H Study of PYD has identified the structure of the SOC measure among adolescents ranging, to date, from fifth to tenth grades (e.g., Gestsdottir, \& Lerner, 2007; Gestsdottir, et al. 2009, 2010). In Grades 5 through 7, the SOC construct exists globally (Gestsdottir, \& Lerner, 2007; Zimmerman, Phelps, \& Lerner, 2007), as opposed to the adult-like structure of three distinct processes. However, reflective of the orthogenetic principle (Werner, 1957), evidence was found for a tripartite, differentiated structure of SOC beginning in the eighth grade as the individual S, O, and $\mathrm{C}$ components identified in older populations (Freund, \& Baltes, 2002) were found in these younger people (Gestsdottir, et al., 2009). However, this work has been "unable to provide [conclusive] evidence against or in support of... differentiation," (Gestsdottir, et al., 2009, p. 591), and other research has modeled the SOC processes using a nine-item subset of the SOC questionnaire across adolescence displaying adequate reliability in both middle and late adolescence (Bowers, et al., 2011). The most recent work on the structure of SOC in adolescence reinforces the utility of the nine-item composite (Geldhof, et al., in press). To be consistent with these findings we calculated a global 9-item SOC for all adolescents, and we calculated separate S, O, and C composite scores for older adolescents. Cronbach's alpha for the older adolescents in the present sample was .45 for Selection, .57 for Optimization, and .26 for Compensation. Cronbach's alpha for the 9-item SOC composite was .74 for the younger adolescents and .61 for the older adolescents in the present sample. 
While these alpha coefficients appear low, low internal consistency is not unexpected as the SOC questionnaire includes heterogeneous facets of each factor (e.g., optimization: investing effort, planning, modeling successful others). There are also several additional reasons why concern over these values is unwarranted. First, Cronbach's alpha is a lower bound estimate of reliability based on Monte Carlo estimates (Cortina, 1993). In addition, some psychometricians have argued that low alphas, even at 0.1 to 0.2 , are sufficient indices on complex constructs (Cattell, 1978). Finally, and most importantly, the reliability data for SOC components has been coupled with concurrent and predictive validity data involving PYD and risk/problem behaviors (Gestsdottir, \& Lerner, 2007; Gestsdottir, et al., 2009; Zimmerman, et al., 2008). Taken this evidence together, the SOC measure is regarded as a useful index of intentional self regulation among adolescents.

Mentoring relationship duration, intensity, and structure. For each youth, mentors were also asked to report on how long they had known the youth (We have just met, A few weeks, Several months, About a year, Several years); how often they met the youth (Less than one time per month, Once per month, Several times per month, Once per week, Several times per week); the duration of each meeting (Less than one hour, About one hour, several hours); and the structure of those meetings (individual, group).

\section{Procedure}

The GPS to Success evaluation involved recruiting and training 4-H staff and agents in North Carolina and Oregon to use the growth grids. This training consisted of an hour and a half interactive webinar conducted by the research team in which the GPS to Success Project was described to mentors, each column of the growth grids was detailed, videos of exemplary models of the skills were shown and discussed, and mentors engaged in guided scoring of vignettes of young people who used the GPS skills and exhibiting the PYD attributes to varying degrees. In order to enhance the reliability and accuracy of reporting on such a diverse set of attributes, we worked to recruit mentor-mentee pairs that were established ( $>$ six months duration of relationships) and saw each other on a regular basis ( $>1$ time per month).

Mentors received login information for themselves and their mentees to complete an online version of the survey via the Internet. In most cases, the programs allocated computers for participants to take the survey online. Mentors and mentees completed the surveys separately. The questionnaires took approximately forty-five minutes to complete, and participants were encouraged to take short breaks if needed.

In order to assess whether the GPS and PYD growth grids were reliable and valid measures of intentional self regulation and PYD, we calculated Cronbach's alphas for each subscale. We also conducted validity assessments that involved point-in-time assessments of covariation of scores derived from: (1) mentor ratings of youth (growth grids); (2) youth self-ratings (growth grids); and (3) youth responses to items from the 4-H Study Student Questionnaire (short version) that involved scores for (a) the Five Cs of PYD; (b) Contribution; and (c) SOC.

\section{Results}

\section{Preliminary analyses}

Of the 69 older adolescents, $7.2 \%(n=5)$ were reported to have known their mentor about a year; and $76.8 \%(n=53)$ were reported to having known their mentor for several years. Eleven youth (15.9\%) were missing information about relationship duration. Based on the prevailing view in the field of mentoring (Rhodes \& Lowe, 2009), these results indicate that 
almost $85 \%$ of mentors reported relationships with older adolescents long enough in duration to report youth attributes accurately.

In regard to dosage, the frequency of mentor-reported contact with youth in general was relatively frequent as almost $75 \%$ of youth were reported to meet with their mentor at least several times per month. Only one youth $(1.4 \%)$ was reported to see their mentor less than one time per month; $24.6 \%(n=17)$ were reported to see their mentors one time per month; $26.1 \%(n=18)$ were reported to see their mentor several times per month; $11.6 \%(n=8)$ were reported to see their mentor once per week; and $20.3 \%(n=14)$ were reported to see their mentor several times per week or more. Again, 11 youth $(15.9 \%)$ were missing information about relationship frequency.

Only $2.9 \%$ of the older adolescents $(n=2)$ were reported to average less than one hour of time together in a typical meeting. Most youth were reported to meet with their mentors about one hour $(31.9 \%, n=22)$ or for several hours during a typical meeting $(47.8 \%, n=33)$. Twelve youth did not have length of visit information reported (17.4\%).

Mentors also reported differences their mentoring practices, such that some mentors met with their youth individually, whereas others met in groups. In our study, $69.6 \%$ of youth $(n=48)$ met with their mentors in groups, and $14.5 \%(n=10)$ met with their mentors individually. Eleven youth (15.9\%) did not have this information available. While there may be some concern with the large proportion of older adolescents meeting with their "mentors" in group settings, we believe that the reported length of relationships, the frequency of contact, and the duration of a typical meeting between mentors and youth provide evidence that the mentors would be accurate reporters of older adolescents GPS skills and PYD attributes. In addition, a recent meta-analysis of mentoring programs for youth reported no differences in effects between group and one-to-one programs, and the effects for both were positive (DuBois, Portillo, Rhodes, Silverthorn, \& Valentine, 2011).

Of the 83 younger adolescents, $1.2 \%(n=1)$ were reported to have known their mentor across a range of time from a few weeks to about a year; $1.2 \%(n=1)$ were reported to have known their mentor for several months; $24.1 \%(n=20)$ were reported to have known their mentors for about a year; and $66.3 \%(n=55)$ were reported to having known their mentor for several years. Six youth (7.2\%) were missing information about relationship duration. Again, these results indicate that over $90 \%$ of mentors reported relationships with younger adolescents long enough in duration to report youth attributes accurately.

In regard to dosage, $2.4 \%(n=2)$ of youth were reported to see their mentor less than one time per month; $36.1 \%(n=30)$ were reported to see their mentors one time per month; $27.7 \%(n=23)$ were reported to see their mentor several times per month; $9.6 \%(n=8)$ were reported to see their mentor once per week; and $16.9 \%(n=14)$ were reported to see their mentor several times per week or more. Again, 6 youth $(15.9 \%)$ were missing information about relationship frequency.

A larger proportion of the younger adolescents $(9.6 \%, n=8)$ were reported to average less than one hour of time together in a typical meeting. However, most youth were reported to meet with their mentors about one hour $(25.3 \%, n=21)$ or for several hours during a typical meeting $(56.6 \%, n=47)$. Seven youth did not have length of visit information reported $(8.4 \%)$. 
The type of program structure experienced by younger adolescents mirrored that of older adolescents. Thirteen youth (15.7\%) met with their mentors individually, whereas $77.1 \%$ $(n=64)$ met with their mentors individually. Six youth $(7.2 \%)$ did not have this information available. As with our older adolescent sample, we believe that any concerns about the structure of the mentoring relationships (i.e., group) for reporting accuracy and validity is offset by the length and intensity of the relationships that were reported.

\section{Main Analyses: The Psychometric Characteristics of the GPS to Success Tools} In general, the results indicated that the GPS, the Five CS of PYD, and Contribution growth grids were reliable measures (see Table 1). Mentors rated youth in a more reliable manner, that is, with high levels of consistency, while youth displayed greater variability in their responses. Cronbach's alphas for the mentor-reported growth grids ranged from a low of .76 for Connection in both younger and older adolescents to a high of .92 for young adolescents' global GPS. Conversely, Cronbach's alphas for the youth-reported growth grids ranged from a low of .42 for older adolescent Competence to a high of .80 for younger adolescent Character and older adolescent Pursuit of Strategies.

Table 1

Reliabilities (as) for mentor- and youth-reported GPS, PYD, and Contribution growth grids for Younger and older adolescents

\begin{tabular}{|l|c|c|c|c|}
\hline Growth Grid & $\begin{array}{c}\text { Older } \\
\text { adolescents, } \\
\text { Mentor- } \\
\text { reported }\end{array}$ & $\begin{array}{c}\text { Older } \\
\text { adolescents, } \\
\text { Self-reported }\end{array}$ & $\begin{array}{c}\text { Younger } \\
\text { adolescents, } \\
\text { Mentor- } \\
\text { reported }\end{array}$ & $\begin{array}{c}\text { Younger } \\
\text { adolescents, } \\
\text { Self-reported }\end{array}$ \\
\hline Competence & .85 & .42 & .85 & .66 \\
\hline Confidence & .76 & .62 & .86 & .73 \\
\hline Connection & .91 & .56 & .76 & .45 \\
\hline Character & .90 & .43 & .85 & .80 \\
\hline Caring & .90 & .78 & .86 & .63 \\
\hline Contribution & .93 & .68 & .92 & .63 \\
\hline GPS - Global & .88 & .65 & NA & NA \\
\hline Goal Selection & .91 & .80 & NA & NA \\
\hline Pursuit of Strategies & .85 & .59 & NA & NA \\
\hline Shifting Gears & & & & .86 \\
\hline
\end{tabular}

The G, P, and S growth grids for older youth did not exhibit good validity when youth scores on the growth grids were correlated with analogous scores on youth-reported 4-H Study questionnaire items pertaining to Selection, Optimization, and Compensation (See Table 2). However, the growth grids for Goal Selection and Pursuit of Strategies were significantly related 
to the global nine-item measure of SOC that has been found to be a reliable and valid index of ISR (e.g., Geldhof, et al., in press; Gestsdottir, et al., 2007). The six-item global GPS score was also significantly correlated to the nine-item global SOC measure for both older and younger adolescents.

Table 2

Correlations for Youth-Reported BPS and SOC Dimensions

\begin{tabular}{|c|c|c|c|c|c|c|c|c|}
\hline & $\begin{array}{c}\text { Goal } \\
\text { Selection } \\
\text { - YR }\end{array}$ & $\begin{array}{c}\text { Pursuit of } \\
\text { Strategies } \\
\text { - YR }\end{array}$ & $\begin{array}{l}\text { Shifting } \\
\text { Gears - } \\
\text { YR }\end{array}$ & $\begin{array}{l}\text { Selection } \\
- \text { YR }\end{array}$ & $\begin{array}{l}\text { Optimization } \\
- \text { - YR }\end{array}$ & $\begin{array}{l}\text { Compensation } \\
- \text {-YR }\end{array}$ & $\begin{array}{c}\text { Global } \\
\text { GPS - } \\
\text { YR }\end{array}$ & $\begin{array}{l}\text { Global } \\
\text { SOC } \\
- \text { YR }\end{array}$ \\
\hline $\begin{array}{l}\text { Goal Selection - } \\
\text { YR }\end{array}$ & - & & & & & & & \\
\hline $\begin{array}{l}\text { Pursuit of } \\
\text { Strategies - YR }\end{array}$ & $.56^{* *}$ & - & & & & & & \\
\hline $\begin{array}{l}\text { Shifting Gears - } \\
\text { YR }\end{array}$ & $.58^{* *}$ & $.43^{* *}$ & - & & & & & \\
\hline Selection - YR & -.04 & -.06 & -.24 & - & & & & \\
\hline $\begin{array}{l}\text { Optimization - } \\
\text { YR }\end{array}$ & -.07 & -.03 & -.01 & $.26^{* *}$ & - & & & \\
\hline $\begin{array}{l}\text { Compensation - } \\
\text { YR }\end{array}$ & .05 & .11 & -.06 & .15 & -.15 & - & & \\
\hline $\begin{array}{l}\text { Global GPS - } \\
\text { YR }\end{array}$ & $.80^{* *}$ & $.85^{* *}$ & $.65^{* *}$ & -.07 & .02 & .09 & - & \\
\hline Global SOC & $.31^{*}$ & $.36^{* *}$ & .22 & $.40^{* *}$ & $.43^{* *}$ & $.28^{* *}$ & $.35^{a^{* *}}$ & - \\
\hline \multicolumn{7}{|c|}{$\begin{array}{l}\text { Notes. } * * \text { Correlation is significant at the } 0.01 \text { level }(2 \text {-tailed). } * \text { Correlation is significant at the } 0.05 \\
\text { level (2-tailed). }\end{array}$} & & \\
\hline
\end{tabular}

When turning to the Five CS of PYD, and youth Contribution, the scores on growth grids were significantly related to the relevant dimension of PYD or Contribution reported through the 4-H Study questionnaire (See Table 3). The correlations across the measures were often higher than the correlations for the scales within each measure (growth grid versus 4-H questionnaire scale). The results suggest that the growth grids are valid indicators of the Five Cs of PYD and youth Contribution. 
Table 3

Correlations for Youth-Reported PYD via Growth Grids and

Five Cs Questionnaire (SQ)

\begin{tabular}{|c|c|c|c|c|c|c|c|c|c|c|c|c|}
\hline PYD Dimension & $\begin{array}{c}\text { Competence } \\
- \text { YR } \\
\end{array}$ & $\begin{array}{c}\text { Confidence } \\
\text { - YR }\end{array}$ & Caring - YR & Character - YR & $\begin{array}{c}\text { Connection } \\
-\mathrm{YR} \\
\end{array}$ & $\begin{array}{c}\text { Contribution } \\
- \text { YR }\end{array}$ & $\begin{array}{c}\text { Competence } \\
-\mathrm{SQ}\end{array}$ & $\begin{array}{c}\text { Confidence } \\
\text { - SQ }\end{array}$ & Caring - SQ & Character - SQ & $\begin{array}{c}\text { Connection } \\
-\mathrm{SQ} \\
\end{array}$ & $\begin{array}{c}\text { Contribution } \\
-\mathrm{SQ} \\
\end{array}$ \\
\hline Competence - YR & - & & & & & & & & & & & \\
\hline Confidence - YR & $.474^{* *}$ & - & & & & & & & & & & \\
\hline Caring - YR & $.51^{* *}$ & $.39^{* *}$ & - & & & & & & & & & \\
\hline Character - YR & $.54^{* *}$ & $.34^{* *}$ & $.55^{* *}$ & - & & & & & & & & \\
\hline Connection - YR & $.43^{* *}$ & $.50^{* *}$ & $.41^{* *}$ & $.34^{* *}$ & - & & & & & & & \\
\hline Contribution - YR & $.45^{* *}$ & $.52^{* *}$ & $.53^{* *}$ & $.49^{* *}$ & $.48^{* *}$ & - & & & & & & \\
\hline Competence - SQ & $.48^{* *}$ & $.49^{* *}$ & $.24^{* *}$ & $.34^{* *}$ & $.23^{* *}$ & $.43^{* *}$ & - & & & & & \\
\hline Confidence - SQ & $.30^{* *}$ & $.42^{* *}$ & 0.16 & $.25^{* *}$ & $.34^{* *}$ & $.30^{* *}$ & $.45^{* *}$ & - & & & & \\
\hline Caring - SQ & $.30^{* *}$ & $.25^{* *}$ & $.40^{* *}$ & $.39^{* *}$ & $.32^{* *}$ & $.35^{* *}$ & $.30^{* *}$ & $.30^{* *}$ & - & & & \\
\hline Character - SQ & $.52^{* *}$ & $.41^{* *}$ & $.54^{* *}$ & $.56^{* *}$ & $.48^{* *}$ & $.52^{* *}$ & $.38^{* *}$ & $.35^{* *}$ & $.61^{* *}$ & - & & \\
\hline Connection - SQ & $.32^{* *}$ & $.41^{* *}$ & $.32^{* *}$ & $.33^{* *}$ & $.56^{* *}$ & $.39^{* *}$ & $.34^{* *}$ & $.55^{* *}$ & $.43^{* *}$ & $.57^{* *}$ & - & \\
\hline Contribution - SQ & $.54^{* *}$ & $.51^{* *}$ & $.50^{* *}$ & $.39^{* *}$ & $.47^{* *}$ & $.67^{* *}$ & $.39^{* *}$ & $.22^{*}$ & $.39^{* *}$ & $.47^{* *}$ & $.47^{* *}$ & - \\
\hline
\end{tabular}

Notes. $* *$ Correlation is significant at the 0.01 level (2-tailed). * Correlation is significant at the 0.05 level (2-tailed). 
Within-rater mentor and youth growth grid scores for GPS and the Five Cs of PYD and Contribution were significantly positively correlated for both older and younger adolescents (Tables 4 and 5, respectively). The strength of these correlations varied across rater, age group, and dimension pairing. However, there were some surprisingly results. For older youth, self-reported Connection was not related to youth Pursuit of strategies nor the global GPS score. Connection was also not related to youth Competence and Character as would be expected in the older youth sample. This lack of a significant relation may be due to a lack of power from a small sample size. Finally, while youth self-reported Character was related to Goal Selection in older youth, Character was not related to the other two dimensions of intentional self regulation. The correlations for the self-reported younger adolescent growth grids also indicated that youth connection was the most weakly related to the global GPS score.

\begin{tabular}{|c|c|c|c|c|c|c|c|c|c|c|}
\hline \multicolumn{11}{|c|}{$\begin{array}{c}\text { Table } 4 \\
\text { Correlations for GPS and PYD Growth Grids for Older Adolescents }\end{array}$} \\
\hline \multicolumn{11}{|c|}{ Youth-Reported } \\
\hline Dimension & $\begin{array}{c}\text { Goal } \\
\text { Selection }\end{array}$ & $\begin{array}{l}\text { Pursuit of } \\
\text { Strategies }\end{array}$ & $\begin{array}{c}\text { Shifting } \\
\text { Gears }\end{array}$ & $\begin{array}{c}\text { Global } \\
\text { GPS }\end{array}$ & Competence & Confidence & Caring & Character & Connection & Contribution \\
\hline $\begin{array}{l}\text { Goal } \\
\text { Selection }\end{array}$ & - & & & & & & & & & \\
\hline $\begin{array}{l}\text { Pursuit of } \\
\text { Strategies }\end{array}$ & $.56^{* *}$ & - & & & & & & & & \\
\hline $\begin{array}{l}\text { Shifting } \\
\text { Gears }\end{array}$ & $.58^{* *}$ & $.43^{* *}$ & - & & & & & & & \\
\hline Global GPS & $.80^{* *}$ & $.85^{* *}$ & $.65^{* *}$ & - & & & & & & \\
\hline Competence & $.53^{* *}$ & $.52^{* *}$ & $.38^{* *}$ & $.54 * *$ & - & & & & & \\
\hline Confidence & $.42^{* *}$ & .18 & $.32^{*}$ & $.40 * *$ & $.38^{* *}$ & - & & & & \\
\hline Caring & $.58^{* *}$ & $.45^{* *}$ & $.45^{* *}$ & $.58^{* *}$ & $.45^{* *}$ & $.29 *$ & - & & & \\
\hline Character & $.31^{*}$ & .26 & .17 & $.28^{*}$ & $.36^{* *}$ & .15 & $.33^{*}$ & - & & \\
\hline Connection & $.46^{* *}$ & .07 & $.39 * *$ & .25 & .25 & $.43^{* *}$ & $.32 *$ & .24 & - & \\
\hline Contribution & $.66^{* *}$ & $.44 * *$ & $.47^{* *}$ & $.54 * *$ & $.44 * *$ & $.41^{* *}$ & $.53 * *$ & $.37 * *$ & $.52^{* *}$ & - \\
\hline \multicolumn{11}{|c|}{ Mentor Reported } \\
\hline $\begin{array}{l}\text { Goal } \\
\text { Selection }\end{array}$ & - & & & & & & & & & \\
\hline $\begin{array}{l}\text { Pursuit of } \\
\text { Strategies }\end{array}$ & $.88^{* *}$ & - & & & & & & & & \\
\hline $\begin{array}{l}\text { Shifting } \\
\text { Gears }\end{array}$ & $.83^{* *}$ & $.84 * *$ & - & & & & & & & \\
\hline Global GPS & $.91^{* *}$ & $.96 * *$ & $.91^{* *}$ & - & & & & & & \\
\hline Competence & $.82^{* *}$ & $.84 * *$ & $.80^{* *}$ & $.86^{* *}$ & - & & & & & \\
\hline Confidence & $.72^{* *}$ & $.78^{* *}$ & $.78^{* *}$ & $.81^{* *}$ & $.88^{* *}$ & - & & & & \\
\hline Caring & $.73^{* *}$ & $.72^{* *}$ & $.70^{* *}$ & $.74 * *$ & $.77^{* *}$ & $.66^{* *}$ & - & & & \\
\hline Character & $.69^{* *}$ & $.67 * *$ & $.63^{* *}$ & $.70^{* *}$ & $.79 * *$ & $.65^{* *}$ & $.76^{* *}$ & - & & \\
\hline Connection & $.75^{* *}$ & $.76^{* *}$ & $.77^{* *}$ & $.80^{* *}$ & $.89 * *$ & $.81^{* *}$ & $.76^{* *}$ & $.84 * *$ & - & \\
\hline Contribution & $.82^{* *}$ & $.84^{* *}$ & $.78^{* *}$ & $.87^{* *}$ & $88^{* *}$ & $.79 * *$ & $.82^{* *}$ & $.83^{* *}$ & $.86^{* *}$ & - \\
\hline
\end{tabular}




\begin{tabular}{|c|c|c|c|c|c|c|c|}
\hline \multirow{2}{*}{\multicolumn{8}{|c|}{$\begin{array}{c}\text { Correlatic } \\
\text { Youth-Reported }\end{array}$}} \\
\hline & & & & & & & \\
\hline Dimension & $\begin{array}{c}\text { Global } \\
\text { GPS }\end{array}$ & Competence & Confidence & Caring & Character & Connection & Contribution \\
\hline Global GPS & - & & & & & & \\
\hline \multirow{2}{*}{$\begin{array}{l}\text { Competence } \\
\text { Confidence }\end{array}$} & $.46^{* *}$ & - & & & & & \\
\hline & $.35 * *$ & $.53 * *$ & - & & & & \\
\hline Caring & $.47^{* *}$ & $.56^{* *}$ & $.47^{* *}$ & - & & & \\
\hline Character & $.38 * *$ & $.61^{* *}$ & $.44^{* *}$ & $.69 * *$ & - & & \\
\hline Connection & $.25^{*}$ & $.55^{* *}$ & $.55^{* *}$ & $.47^{* *}$ & $.42^{* *}$ & - & \\
\hline Contribution & $.35 * *$ & $.47 * *$ & $.61^{* *}$ & $.55^{* *}$ & $.60^{* *}$ & $.45^{* *}$ & - \\
\hline \multicolumn{8}{|c|}{ Mentor Reported } \\
\hline \multicolumn{2}{|l|}{ Global GPS } & & & & & & \\
\hline Competence & $.85^{* *}$ & - & & & & & \\
\hline Confidence & $.70^{* *}$ & $.82^{* *}$ & - & & & & \\
\hline Caring & $.75^{* *}$ & $.78^{* *}$ & $.63^{* *}$ & - & & & \\
\hline Character & $.71^{* *}$ & $.81^{* *}$ & $.68^{* *}$ & $.84 * *$ & - & & \\
\hline Connection & $.74 * *$ & $.85^{* *}$ & $.79 * *$ & $.73^{* *}$ & $.79 * *$ & - & \\
\hline Contribution & $.83^{* *}$ & $.79 * *$ & $.78^{* *}$ & $.71^{* *}$ & $.73^{* *}$ & $.82^{* *}$ & - \\
\hline \multicolumn{8}{|c|}{ Notes. ${ }^{* *}$ Correlation is significant at the 0.01 level (2-tailed). } \\
\hline
\end{tabular}

When turning to the mentor-reported growth grid scores, the results indicate that all of the dimensions were strongly related to each other for both younger and older adolescents. The smallest correlation for the mentor-reported growth grids was between Shifting Gears and Character in older youth, $r(55)=.63, p<.01$. This value is greater than most of the correlations found for the self-reported indices. Taken together with the reliability results (Table 1 ), these results suggest that mentors perceive youth as well-functioning in a global manner.

The final set of analyses examined the correlations across raters (youth versus mentor) in order to investigate cross-rater reliability (Tables 6 and 7). The results show that for the $G, P$, and $S$ dimensions in older youth, mentor and youth reports were only significantly correlated for Shifting Gears, $r(43)=.43, p<.0$ (See Table 6). However, youth reports of Shifting Gears were also significantly correlated with mentor-reported Goal Selection and Pursuit of Strategies. The results also lend support to the use of the global GPS growth grid as a valid measure of intentional self regulation for both younger and older youth as the mentor-reported global measure was significantly related to older youth Goal Selection and Pursuit of Strategies, the youth-reported global GPS measure was related to mentor-reported Pursuit of strategies and Shifting Gears, and the global measure of GPS was significantly correlated across-raters. 


\begin{tabular}{|c|c|c|c|c|c|c|c|c|}
\hline \multicolumn{9}{|c|}{$\begin{array}{r}\text { Table } 6 \\
\text { Mentor and Youth Correlations for GP }\end{array}$} \\
\hline $\begin{array}{l}\text { Growth Grid } \\
\text { Dimension }\end{array}$ & $\begin{array}{c}\text { Goal } \\
\text { Selection } \\
- \\
\text { YR }\end{array}$ & $\begin{array}{c}\text { Pursuit of } \\
\text { Strategies } \\
- \\
\text { YR }\end{array}$ & $\begin{array}{c}\text { Shifting } \\
\text { Gears } \\
- \\
\text { YR }\end{array}$ & $\begin{array}{c}\text { Goal } \\
\text { Selection } \\
- \\
\text { MR }\end{array}$ & $\begin{array}{c}\text { Pursuit of } \\
\text { Strategies } \\
- \\
\text { MR }\end{array}$ & $\begin{array}{c}\text { Shifting } \\
\text { Gears } \\
- \\
\text { MR }\end{array}$ & $\begin{array}{c}\text { Global } \\
\text { GPS } \\
- \\
\text { YR }\end{array}$ & $\begin{array}{c}\text { Global } \\
\text { GPS } \\
- \\
\text { MR }\end{array}$ \\
\hline $\begin{array}{l}\text { Goal Selection } \\
- \text { YR }\end{array}$ & - & & & & & & & \\
\hline $\begin{array}{l}\text { Pursuit of } \\
\text { Strategies-YR }\end{array}$ & $.56^{* *}$ & - & & & & & & \\
\hline $\begin{array}{l}\text { Shifting Gears } \\
\text { - YR }\end{array}$ & $.58^{* *}$ & $.43^{* *}$ & - & & & & & \\
\hline $\begin{array}{l}\text { Goal Selection } \\
-M R\end{array}$ & .27 & .22 & $.37^{*}$ & - & & & & \\
\hline $\begin{array}{l}\text { Pursuit of } \\
\text { Strategies-MR }\end{array}$ & $.37^{*}$ & .25 & $.45^{* *}$ & $.88^{* *}$ & - & & & \\
\hline $\begin{array}{l}\text { Shifting Gears } \\
\text {-MR }\end{array}$ & .28 & .14 & $.43^{* *}$ & $.83^{* *}$ & $.84 * *$ & - & & \\
\hline $\begin{array}{l}\text { Global GPS } \\
- \text { YR }\end{array}$ & & & & $.30^{*}$ & $.35^{*}$ & .22 & - & \\
\hline $\begin{array}{l}\text { Global GPS } \\
\text {-MR }\end{array}$ & $.33^{*}$ & .19 & $.41^{* *}$ & & & & $.31^{\mathrm{a} * *}$ & \\
\hline
\end{tabular}




\begin{tabular}{|c|c|c|c|c|c|c|c|c|c|c|c|c|}
\hline \multicolumn{13}{|c|}{$\begin{array}{c}\text { Table } 7 \\
\text { Mentor and Youth Correlations for PYD Growth Grid Dimensions }\end{array}$} \\
\hline $\begin{array}{l}\text { PYD } \\
\text { Dimension }\end{array}$ & $\begin{array}{c}\text { Competence } \\
-Y R\end{array}$ & 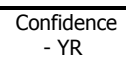 & $\begin{array}{l}\text { Caring } \\
-Y R\end{array}$ & $\begin{array}{c}\text { Character } \\
-Y R\end{array}$ & $\begin{array}{c}\begin{array}{c}\text { Connection } \\
-Y R\end{array} \\
\text { - }\end{array}$ & $\begin{array}{c}\text { Contribution } \\
-Y R\end{array}$ & $\begin{array}{c}\text { Competence } \\
\text { - MR }\end{array}$ & $\begin{array}{c}\text { Confidence } \\
\text { - MR }\end{array}$ & $\begin{array}{l}\text { Caring } \\
-M R\end{array}$ & $\begin{array}{c}\text { Character } \\
\text { - MR }\end{array}$ & $\begin{array}{c}\text { Connection } \\
\text { - MR }\end{array}$ & $\begin{array}{c}\text { Contribution } \\
-M R\end{array}$ \\
\hline $\begin{array}{l}\text { Competence } \\
-Y R\end{array}$ & - & & & & & & & & & & & \\
\hline $\begin{array}{l}\text { Confidence } \\
\text { - YR }\end{array}$ & $.47 * *$ & - & & & & & & & & & & \\
\hline $\begin{array}{l}\text { Caring } \\
-Y R\end{array}$ & $.51 * *$ & $.39 * *$ & - & & & & & & & & & \\
\hline $\begin{array}{l}\text { Character } \\
- \text { YR }\end{array}$ & $.54 * *$ & $.34 * *$ & $.55 * *$ & - & & & & & & & & \\
\hline $\begin{array}{l}\text { Connection } \\
-\mathrm{YR}\end{array}$ & $.43 * *$ & $.45 * *$ & $.41^{* *}$ & $.34 * *$ & - & & & & & & & \\
\hline $\begin{array}{l}\text { Contribution } \\
-\mathrm{YR}\end{array}$ & $.45 * *$ & $.52 * *$ & $.53^{* *}$ & $.49 * *$ & $.48^{* *}$ & - & & & & & & \\
\hline $\begin{array}{l}\text { Competence } \\
\text { - MR }\end{array}$ & $.29 * *$ & $.35 * *$ & .12 & $.22 *$ & $.25^{* *}$ & $.25 * *$ & - & & & & & \\
\hline $\begin{array}{l}\text { Confidence } \\
\text { - MR }\end{array}$ & $.26 * *$ & $.34 * *$ & .07 & .18 & $.24 *$ & $.28^{* *}$ & $.85 * *$ & - & & & & \\
\hline $\begin{array}{l}\text { Caring } \\
-M R\end{array}$ & $.24 *$ & $.30 * *$ & .14 & .17 & $.19 *$ & .16 & $.78^{* *}$ & $.65^{* *}$ & - & & & \\
\hline $\begin{array}{l}\text { Character } \\
\text { - MR }\end{array}$ & $.21 *$ & $.27^{* *}$ & .04 & .15 & .17 & .17 & $.80^{* *}$ & $.67^{* *}$ & $.81^{* *}$ & - & & \\
\hline $\begin{array}{l}\text { Connection } \\
\text { - MR }\end{array}$ & $.22^{*}$ & $.32^{* *}$ & .14 & $.21^{*}$ & $.21 *$ & $.21 *$ & $.87^{* *}$ & $.81^{* *}$ & $.75^{* *}$ & $.81^{* *}$ & - & \\
\hline $\begin{array}{l}\text { Contribution } \\
-\mathrm{MR}\end{array}$ & $.25^{* *}$ & $.30^{* *}$ & .10 & .17 & $.20 *$ & $.25^{* *}$ & $.83 * *$ & $.79 * *$ & $.76^{* *}$ & $.76 * *$ & $.84 * *$ & - \\
\hline
\end{tabular}

Across-rater correlations for the Five Cs of PYD and youth Contribution were more problematic (See Table 7). For all pairs, correlations between analogous $C$ growth grid scores were significant for Competence, Confidence, Connection, and Contribution, but these values were low (ranging from $r=.21$ to $r=.34$ ). Correlations between youth and mentors on Caring and Character were in the right direction, but quite low. The discussion details possible reasons for these low levels of reliability. However, these initial evaluation findings pertinent to the psychometric quality of the GPS to Success tools suggested that the growth grids were suitable for larger-scale use.

\section{Discussion}

Intentional self regulation (ISR) has been linked consistently across the adolescent years to positive youth development (PYD) and youth contribution (e.g., J. Lerner, et al., 2012). ISR, as a key individual strength of youth, results in these features of youth thriving when enacted in the context of key ecological developmental assets, such as youth development programs having competent, reliable, and devoted adults serving as mentors to youth (e.g., Benson, Scales, \& Syvertsen, 2011; Rhodes, \& Lowe, 2009; Theokas, \& Lerner, 2006. The 4-H Study uses a model of ISR that operationalizes this construct as involving the selection of positive goals, optimizing ones chances of attaining ones goals through using effective strategies of resource recruitment and/or the cognitive and behavioral skills reflected in executive functioning, and compensating when goals are blocked or when strategies fail (Baltes, \& Baltes, 1990; Freund, \& Baltes, 2002; Lerner, at al., 2011a). The 4-H Study of PYD (e.g., Lerner, et al., 
2005, 2009, 2010, 2011b) has provided longitudinal data documenting the links among ISR, PYD, and youth Contribution. The study verifies that covariation exists as well among these links and youth development programs, and the mentoring occurring within them.

The goal of the 4-H Study was to not only describe and explain these patterns of association among youth strengths, such as ISR; ecological assets, such as mentors within youth development programs; and youth thriving (as indexed by scores for PYD and youth Contribution) but, as well, the intent was to use this research base to devise means to optimize positive development among youth (Lerner, Lerner, \& Benson, 2011). Because there are few tools derived from theory-predicated developmental research that can be used by mentors to enhance the links among ISR and PYD or youth Contribution, we sought to develop a set of tools derived from the findings of the 4-H Study for potential use by the practitioners involved in mentoring youth in community-based programs. The present article presented initial information about the psychometric quality of the tools we have developed, that is the GPS to Success growth grids (rubrics), which - as we have explained - use the metaphor of a GPS navigational system (" $G$ " standing for goal selection, "P" standing for pursuit of strategies, and " $S$ " standing for shifting gears, or compensatory skills needed when goals are blocked or when strategies fail). We also developed growth grids assessing the Five Cs of PYD (competence, confidence, connection, character, and caring) and youth Contribution.

We believe that our results are promising in regard to the reliability and validity of these growth grid tools, at least among the younger and older adolescents and their mentors who were involved in 4-H program sites in Oregon and North Carolina. This research is limited to assessing these psychometric characteristics at one point in time within the program experiences of youth and mentors. There are nevertheless indications of modest to high levels of reliability in both younger and older youth scoring of the growth grids, somewhat higher levels of reliability in regard to the scores on the rubrics provided by the mentors and, as well, scores indicative of validity. For instance, validity was evidenced by the findings that rubric scores for " $G$ " and " $P$ " and for the global GPS score were significantly related to the measure of ISR developed by Freund and Baltes (2002). Validity was evidenced also by findings that withinpair mentor and youth growth grid scores for GPS, the Five Cs, and Contribution were significantly positively correlated.

We are therefore encouraged that there is sufficient evidence of the psychometric quality of the tools to promote their further use in longitudinal assessments of their usefulness and measurement quality. We intend to conduct such research in a manner mindful of the several limitations of the present research. Our further plans for developing the measurement quality of these tools involves not only longitudinal assessments but, as well, use of samples that extend beyond the two geographic areas assessed in the present research and, as well, that include more racially and ethnically diverse youth than involved in the present research. In addition, we will study youth involved in programs other than $4-\mathrm{H}$ and, in this context, explore as well how program dosage and program type may moderate the psychometric quality of the growth grids. For instance, we would expect that youth involved in programs of greater intensity and duration might - within the context of the mentoring they experience - show not only growth in their ISR skills and in the links between ISR and indices of thriving but, in addition, they might evidence increasing convergence between their self appraisals on the rubrics and the appraisals of their mentors. Here, it will be interesting to see whether, if such relations exist, they vary in relation to participation in different youth development programs. Again, the testing of these ideas awaits further longitudinal research. 
Nevertheless, we can conclude that the present research has provided encouraging evidence that the research developed within the 4-H Study of PYD can be translated into tools useful for mentors to employ in their efforts to enhance a key individual strength among youth - ISR. Thus, mentors can use the "GPS to Success" tools to catalyze the use of this strength among youth. Mentors can help youth engage their context to effectively pursue goals and to access the ecological resources associated with them, developmental assets that enable young people to thrive (Benson, et al., 2011). If the quality of these tools can be enhanced through further tool-development research, we believe that the importance of applied longitudinal research, such as the 4-H Study, will be underscored. Most important, there will be a documentation of the importance of evidence-based tools in facilitating mentors enacting their vital contributions to promote youth strengths and thriving.

Acknowledgment: This research was supported in part by grants from the Thrive Foundation for Youth and the John Templeton Foundation.

\section{References}

Andrade, H.G. (2000). Using rubrics to promote thinking and learning. Educational Leadership, 57(5): 13-18.

Baltes, P.B. (1997). On the incomplete architecture of human ontogeny: Selection, optimization, and compensation as foundations of developmental theory. American Psychologist, 52, 366380.

Baltes, P.B., \& Baltes, M.M. (1990). Psychological perspectives on successful aging: The model of selective optimization with compensation. In P.B. Baltes \& M.M. Baltes (Eds.), Successful aging: Perspectives from the behavioral sciences (pp. 1-34). New York: Cambridge University Press.

Baltes, P.B., Lindenberger, U., \& Staudinger, U.M. (2006). Lifespan theory in developmental psychology. In R.M. Lerner (Ed.), Theoretical models of human development. Vol. 1: Handbook of Child Psychology (6 ${ }^{\text {th }}$ ed., pp. 569-664). Editors-in-chief: W. Damon \& R.M. Lerner. Hoboken, NJ: Wiley.

Benson, P.L. (2008). Sparks: How parents can help ignite the hidden strengths of teenagers. San Francisco, CA: Jossey-Bass.

Benson, P.L., Leffert, N., Scales, P.C., \& Blyth, D.A. (1998). Beyond the 'village' rhetoric: creating healthy communities for children and adolescents. Applied Developmental Science, 2(3), 138-159.

Benson, P.L., Scales, P.C., \& Syvertsen, A.K. (2011). The contribution of the developmental assets framework to positive youth development theory and practice. In R.M. Lerner, J.V. Lerner, \& J.B. Benson (Eds.), Advances in Child Development and Behavior, 41, 195-228.

Bowers, E.P., Li, Y., Kiely, M.K., Brittian, A., Lerner, J.V., \& Lerner, R.M. (2010). The Five Cs Model of Positive Youth Development: A longitudinal analysis of confirmatory factor structure and measurement invariance. Journal of Youth and Adolescnce, 39(7), 720-735. 
Bowers, E.P., Gestsdóttir, S., Geldhof, J., Nikitin, J., von Eye, A., \& Lerner, R.M. (2011). Developmental trajectories of intentional self regulation in adolescence: The role of parenting and implications for positive and problematic outcomes among diverse youth. Journal of Adolescence, 34(6), 1193-1206.

Brandtstädter, J. (1989). Personal self-regulation of development: Cross-sequential analyses of development-related control beliefs and emotions. Developmental Psychology, 25, 96-108.

Cattell, R.B. (1978). Scientific use of factor analysis in behavioral and life sciences. New York: Plenum Press.

Cortina, J.M. (1993). What is Coefficient Alpha? An examination of theory and applications. Journal of Applied Psychology, 78, 98-104.

Cunha, F., Heckman, J., \& Schennach, S. (2010) Estimating the technology of cognitive and noncognitive skill formation. Econometrica, 78, 883-931.

Damon, W. (2008). The path to purpose: Helping our children find their calling in life. New York: Simon and Schuster.

DuBois, D. L., Portillo, N., Rhodes, J. E., Silverthorn, N., Valentine, J. C. (2011). How Effective Are Mentoring Programs for Youth? A Systematic Assessment of the Evidence. Psychological Science in the Public Interest, 12, 57-91.

Dweck, C.S. (2006). Mindset: The new psychology of success. New York: Random House.

Eccles, J.S. (2004). Schools, academic motivation, and stage-environment fit. In. R.M. Lerner \& L. Steinberg (Eds.). Handbook of adolescent psychology (Vol. 2, pp. 125-153). Hoboken, NJ: Wiley.

Freud, A. (1969). Adolescence as a developmental disturbance. In G. Caplan \& S. Lebovici (Eds.), Adolescence (pp. 5-10). New York: Basic Books.

Freund, A.M., \& Baltes, P.B. (2002). Life-management strategies of Selection, Optimization and Compensation: Measurement by self-report and construct validity. Journal of Personality and Social Psychology, 82, 642-662.

Freund, A.M., Li, Z.H., \& Baltes, P.B. (1999). The role of selection, optimization, and compensation in successful aging. In J. Brandtstädter \& R.M. Lerner (Eds.), Action and development: Origins and functions of intentional self-development (pp. 401-434). Thousand Oaks: Sage.

Geldhof, G.J., Little, T.D., \& Colombo, J. (2010). Self-regulation across the life span. In R.M. Lerner (Ed.), M.E. Lamb, \& A.M. Freund (Volume Eds.), Handbook of Life-span Development, Vol. 2. Social and emotional development (pp. 116-157). Hoboken, NJ: Wiley.

Geldhof, G.J., Bowers, E.P., Gestsdottir, S., Napolitano, C.M., \& Lerner, R.M. (in press). The Structure of Selection, Optimization, and Compensation in Adolescence: Addressing an Unsolved Issue. Journal of Research on Adolescence.

Gestsdóttir, S., Almerigi, J.B., \& Lerner, R.M. (2007). Developmental Systems Theory. In R.S. New, \& M. Cochran (Eds.), Early Childhood Education: An International Encyclopedia. Vol. 1 (pp. 286-288). Westport, Connecticut: Praeger. 
Gestsdóttir, S., \& Lerner, R.M. (2007). Intentional self-regulation and positive youth development in early adolescence: Findings from the 4-H Study of Positive Youth Development. Developmental Psychology, 43(2), 508-521.

Gestsdóttir, G., \& Lerner, R.M. (2008). Positive development in adolescence: The development and role of intentional self regulation. Human Development, 51, 202-224.

Gestsdóttir, S., Lewin-Bizan, S., von Eye, A., Lerner, J.V. \& Lerner, R.M. (2009). The structure and function of Selection, Optimization, and Compensation in middle adolescence: Theoretical and applied implications. Journal of Applied Developmental Psychology, 30(5), 585-600.

Gestsdottir, S., Bowers, E.P., von Eye, A., Napolitano, C.M., \& Lerner, R.M. (2010). Intentional self regulation in middle adolescence: The emerging role of loss-based selection in Positive Youth Development. Journal of Youth and Adolescence, 39(7), 764-782.

Goodrich, H. (1997). Understanding rubrics. Educational Leadership, 54(4), 14-17.

Kuhn, D. (2009). Adolescent thinking. In R.M. Lerner, L. Steinberg, (Eds.), Handbook of adolescent psychology, Vol 1: Individual bases of adolescent development (3rd ed.) (pp. 152186). Hoboken, NJ US: John Wiley \& Sons Inc.

Kurtines, W.M., Ferrer-Wreder, L., Berman, S.L., Cass Lorente, C., Briones, E., Montgomery, M.J., et al. (2008b). Promoting positive youth development: The Miami Youth Development Project (YDP). Journal of Adolescent Research, 23, 256-267.

Larson, R.W. (2000). Toward a psychology of positive youth development. American Psychologist, 55(1), 170-183.

Larson, R. (2006). Positive youth development, willful adolescents, and mentoring. Journal of Community Psychology, 34(6), 677 - 689.

Lerner, J.V., Bowers, E.P., Minor, K., Lewin-Bizan, S., Boyd, M.J., Mueller, M.K., et al. (2012). Positive youth development: Processes, philosophies, and programs. In R.M. Lerner, M.A., Easterbrooks, \& J. Mistry (Eds.), Handbook of Psychology, Volume 6: Developmental Psychology ( $2^{\text {nd }}$ edition). Editor-in-chief: I.B. Weiner. (pp. 365-392). Hoboken, NJ: Wiley.

Lerner, R.M., Lerner, J.V., Almerigi, J., Theokas, C., Phelps, E., Gestsdottir, S., et al. (2005). Positive youth development, participation in community youth development programs, and community contributions of fifth grade adolescents: Findings from the first wave of the 4-H Study of Positive Youth Development. Journal of Early Adolescence, 25(1), 17-71.

Lerner, R.M., Lerner, J.V., \& Benson, J. B. (2011). Research and applications for promoting thriving in adolescence: A view of the issues. In R.M. Lerner, J.V. Lerner, \& J.B. Benson, (Eds.), Advances in Child Development and Behavior: Positive youth development: Research and applications for promoting thriving in adolescence (pp. 1-16). Amsterdam: Elsevier Publishing.

Lerner, R.M., Lerner, J.V., Bowers, E.P., Lewin-Bizan, S., Gestsdottir, S, \& Urban, J. (2011). Thriving in childhood and adolescence: The role of self regulation processes. New Directions for Child and Adolescent Development, 133.

Lerner, R.M., Lerner, J.V., von Eye, A., Bowers, E.P., \& Lewin-Bizan, S. (2011). Individual and contextual bases of thriving in adolescence: A view of the issues. Journal of Adolescence. 
Lerner, R.M., von Eye, A., Lerner, J.V., \& Lewin-Bizan, S. (2009). Exploring the foundations and functions of adolescent thriving within the 4-H study of positive youth development: A view of the issues. Journal of Applied Developmental Psychology, 30(5), 567-570.

Lerner, R.M., von Eye, A., Lerner, J.V., Lewin-Bizan, S., \& Bowers, E.P. (2010). Special issue introduction: The meaning and measurement of thriving: A view of the issues. Journal of Youth and Adolescence, 39(7), 707-719.

Lerner, R.M. (2004). Liberty: Thriving and civic engagement among America's youth. Thousand Oaks, CA: Sage Publications.

Marzano R.J., \& Haystead, M.W. (2008). Making standards useful in the classroom. Alexandria, VA: Association for Supervision and Curriculum Development.

McClelland, M.M., Ponitz, C.C., Messersmith, E.E., \& Tominey, S. (2010). Self-regulation: The integration of cognition and emotion. In W.R. Overton (Ed.), Cognition, Biology, and Methods across the Life Span: Vol. 1, Handbook of Life-span Development. Editor-in-chief: R.M. Lerner. (pp. 509-553). Hoboken, NJ: Wiley.

Moshman, D. (2013). Adolescent rationality. Advances in Child Development and Behavior, 45, 155-184.

Moskal, B.M. (2003). Recommendations for developing classroom performance assessments and scoring rubrics. Practical Assessment, Research \& Evaluation, 8(14). Available http://PAREonline.net/getvn.asp?v=8\&n=14 .

Paus, T. (2009). Brain development. In R.M. Lerner, L. Steinberg (Eds.), Handbook of adolescent psychology, Vol 1: Individual bases of adolescent development ( $3^{\text {rd }}$ ed.) (pp. 95115). Hoboken, NJ US: John Wiley \& Sons Inc.

Popham, J.W. (1997). What's wrong-and what's right-with rubrics. Educational Leadership, $55(2): 72-75$.

Rhodes, J.E., \& Lowe, S.R. (2009). Mentoring in adolescence. In R.M. Lerner, L. Steinberg, (Eds.), Handbook of Adolescent Psychology: Vol. 2. Contextual Influences on Adolescent Development ( $3^{\text {rd }}$ ed., pp. 152-190). Hoboken, NJ: John Wiley \& Sons Inc.

Small, S.A., \& Rodgers, K.B. (1995). Teen Assessment Project (TAP) Survey Question Bank. Madison, WI: University of Wisconsin-Madison.

Susman, E.J., \& Dorn, L.D. (2009). Puberty: Its Role in Development. In R.M. Lerner, L. Steinberg, (Eds). Handbook of Adolescent Psychology ( $3^{\text {rd }}$ ed.). (pp. 116-151). Hoboken, NJ: John Wiley \& Sons.

Templeton, J.M. (2012). The essential worldwide laws of life. Radnor, PA: Templeton Foundation Press.

Theokas, C., \& Lerner, R.M. (2006). Observed Ecological Assets in Families, Schools, and Neighborhoods: Conceptualization, Measurement and Relations with Positive and Negative Developmental Outcomes. Applied Developmental Science, 10(2), 61-74. 
Werner, H. (1957). The concept of development from a comparative and organismic point of view. In D.B. Harris (Ed.), The concept of development (pp. 125-148). Minneapolis: University of Minnesota.

Zimmerman, S., Phelps, E., \& Lerner, R.M. (2007). Intentional self-regulation in early adolescence: Assessing the structure of selection, optimization, and compensations processes. European Journal of Developmental Science, 1(3), 272-299.

Zimmerman, S., Phelps, E., \& Lerner, R.M. (2008). Positive and negative developmental trajectories in U.S. adolescents: Where the PYD perspective meets the deficit model. Research in Human Development,5(3),153-165.

(C) Copyright of Journal of Youth Development $\sim$ Bridging Research and Practice. Content may not be copied or emailed to multiple sites or posted to a listserv without copyright holder's express written permission. Contact Editor at: patricia.dawson@oregonstate.edu for details. However, users may print, download or email articles for individual use.

ISSN 2325-4009 (Print); ISSN 2325-4017 (Online) 


\section{Appendix 1 \\ Descriptions of GPS and the Cs of PYD}

(G) Goal Selection

Before an adolescent can achieve a goal, he or she must choose that goal and understand the steps needed for goal achievement. In the GPS framework, these behaviors are called "Goal Selection" (or G) behaviors.

Choosing Your Destination - This behavior is the ability for a youth to select one or a small number of meaningful, realistic and demanding long-term goals, for example, getting into college or joining an athletic team.

Goals That Help Others - Long-term goals, goals that are the destination of youth, should help themselves and also help the community, whether it be family, school, neighborhood, or the environment.

Breaking Down Long Term Goals (Vertical Coherence) - Thriving adolescents are able to select long-term goals that can be broken into short-term steps along the way. Having logical and achievable short-term goals within a long-term goal improves the likelihood of attaining that goal.

Identifying Relations Among Goals (Horizontal Coherence) - The best kinds of goals help youth out in many different parts of life, and can even help youth to achieve other goals. For example, the goal of joining a sports team helps youth become both physically fit and make friends.

\section{(P) Pursuit of Strategies}

After selecting a goal, an adolescent must then use and/or develop the strategies needed to achieve that goal. In the GPS framework, these behaviors are called "Pursuit of Strategies", (or P) behaviors.

Sticking to a Plan - Making a detailed, step-by-step plan - and sticking to it by staying focused - increases the likelihood that an individual will successfully achieve a goal.

Seizing the Moment - In order to achieve their goals, youth often have to know when and how to act. To seize the moment, youth must be aware of their environment, and know when and how to use their strategies most appropriately. For example, a youth may wait to ask his parents for help when they are in a good mood.

Developing Strategies - In order to achieve their goals, youth must develop strategies that will help them along the way. Sometimes, these may be strategies they already possess, such as studying to prepare for a test. Other times, it might mean looking for new strategies in the environment such as joining a study group to prepare for a test. It might also mean that youth refine, or practice, the strategies that they are already using.

Showing Persistent Effort - Just having the right strategies in place isn't enough for a youth to achieve his or her goals. They must stay focused and show persistent effort with their strategies, resisting the temptation (at least most of the time) to be distracted by other things that may lead them off the path to goal achievement.

Checking Your Progress - An important - and often-overlooked - strategy for achieving goals is keeping track of goal progress, and specifically, which strategies are working and which are not. Some youth may do this primarily mentally, keeping track "in their head" about how things are going and what is working and what isn't. Other youth might need more structure to check up on their progress. 


\section{(S) Shifting Gears}

Sometimes the strategies that we use don't work as well we planned. However, "roadblocks" don't necessarily mean that the goal is wrong; rather, there might be something not working with our strategies. In other words, with some adjustments, there is still hope to achieve the goal. In the GPS model, these are called "Shifting Gears" (or S) behaviors.

Substituting Strategies - Sometimes, a youth's first choice of strategies won't work quite as well as they had planned for a particular goal. Keeping that long-term goal a reality requires some adjustment or substitution of strategies. Youth might have to change their plans, but the goal remains the same.

Seeking Different Help - When youth run into trouble or their original plans do not work out, they often need to seek help from new and familiar people and resources to reach their goals.

Adopting the Strategies of Others - One of the most important ways that youth can find new strategies is by modeling or emulating the successful behavior of others. Society is full of success stories, and often these individuals provide excellent advice for youth who are struggling to achieve their goals.

Changing Goals Without Feeling Bad, or Loss-Based Selection (LBS) - LBS is all about changing goals when things aren't working as planned. Recognizing the need to move to a new, more appropriate goal, LBS is about accepting loss as part of the learning process, analyzing options and keeping an overall long-term goal in perspective.

\section{What is PYD?}

Positive Youth Development (PYD) is the capacity for all young people to Thrive. Whether it is through their own actions and abilities, or through the support of caring adults and youthserving organizations, ALL young people can lead healthy, happy lives. Studies from Tufts University and other research centers show that PYD is made up of Five Cs that are linked to youths' positive development: Competence, Confidence, Connection, Character, and Caring. When youth are developing positively and reach the highest level of the Five $\mathrm{Cs}$, they are more likely to become active citizens and develop a sense of Contribution, a sixth C.

\section{Competence}

Competence is defined as a young person's ability to perform successfully in a number of different areas, such as social, academic, cognitive, and self-care skills.

Academic Competence - Youth's ability to develop academic skills, participates in school activities, and uses personal and academic resources for success in school.

Cognitive Competence - Youth's ability to display curiosity and initiative to learn outside of school settings, which leads to skills in these areas.

Social Competence - Youth's ability to interact successfully in different situations with people of various ages and cultures.

Emotional Competence - Youth's ability to identify, control and adapt emotions in different situations.

Healthy Habits - Youth's ability to make healthy life choices by taking care of self with good diet, rest, and exercise, while avoiding unsafe behaviors.

\section{Confidence}

Confidence is defined as a young person's beliefs in his or her abilities to achieve in a variety of domains.

Overall Confidence - Youth's internal sense of overall positive self-worth and efficacy. Confidence in School - Youth's confidence in ability to succeed in an academic setting. 
Confidence in Physical Appearance - Youth's confidence in dress, hygiene, and features.

Confidence in Peer Acceptance - Youth's confidence in ability to make and keep friendships.

Confidence in an Area of Interest - Youth's personal belief for success in a valued area.

\section{Caring}

Caring is defined by the sense of sympathy and empathy that a young person has for others, as well as a dedication to social justice. A caring young person is not satisfied with just having his or her own needs met, but is also concerned with the needs of others. Caring includes the expectation that everyone should have equal opportunities and be free from discrimination.

Sympathy - Youth's support and concern for the emotions of others.

Empathy - Youth's ability to relate to others' emotions and experiences, and ability to place one's self "in the other person's shoes."

Caring Actions - How kind and helpful youth's behaviors are towards other people. Promoting Social Justice - Youth's willingness to help a community in need by working for fairness and equality.

\section{Connection}

Connection is measured by the quality of relationships that a young person has with other people and social groups.

Connection with Family - How well youth maintains healthy relationships with family members, uses open communication skills, and deals with problems.

Connection with Friends - How well youth maintains strong, healthy relationships with friends and is able to connect with many peers.

Connection with Community - How well youth creates successful relationships with community members and institutions, and is able to improve and expand these ties.

\section{Character}

Character is defined as having a sense of morality - beliefs in standards for the behavior of oneself and others - and the belief that integrity is an important part of a thriving life.

Character can also be described as doing what's best for yourself and society.

Moral Compass - Youth's sense of right and wrong that guides them in situations and whether youth uses moral emotions (empathy, sympathy, admiration, shame, guilt, anger, self-esteem) rather than snap judgments to make decisions.

Integrity - Youth's ability to show sense of right and wrong in actions and ability to monitor self to see if actions are consistent with beliefs.

Equal Treatment of Others - Youth's equal and fair treatment of others, regardless of who the others are and youth's ability to stand up for the fair treatment of everyone.

\section{Contribution}

When the Five Cs are present in a young person, then a sixth $C$, Contribution, can emerge. Contribution describes a person's ability and desire to give back and contribute to his family, community, and society.

Service to Community - Youth's level of service to the community, such as getting involved in service projects.

Leadership Roles - Youth's ability and initiative to lead in a positive way.

Mentoring Peers - Youth's willingness to mentor peers who need help.

Sense of Positive Purpose - Youth's sense of purpose and desire to contribute now and in the future. 